УДК 616.94:617(471.34)

Ю. Ю. Нікуліна, К. В. Лаврентьєва, Н. В. Черевач, О. А. Сірокваша, А. І. Вінніков

Дніпропетровський національний університет ім. Олеся Гончара

Дніпропетровська обласна клінічна лікарня ім. І. І. Мечникова

\title{
БІОЛОГІЧНІ ВЛАСТИВОСТІ БАКТЕРІЙ РОДУ STAPHYLOCOCCUS, ВИДІЛЕНИХ ВІД ПАЦІЕНТІВ ДНІПРОПЕТРОВСЬКОЇ КЛІНІЧНОЇ ЛІКАРНІ ім. І. І. МЕЧНІКОВА
}

Досліджено біологічні властивості 494 штамів бактерій роду Staphylococcus, виділених із патологічного матеріалу паціснтів 15 відділень Дніпропетровської обласної клінічної лікарні ім. І. І. Мечникова. Досліджена мікрофлора представлена чотирма видами бактерій: Staphylococcus aureus, S. epidermidis, S. haemolyticus та S. saprophyticus. Найпоширеніший збудник стафілококових інфекцій золотистий стафілокок. Найчутливішими виділені бактерії виявилися до лінезоліду, гентаміцину та меропенему.

Ю. Ю. Никулина, Е. В. Лаврентьева, Н. В. Черевач, Е. А. Сирокваша, А. И. Винников

Днепропетровский национальный университет им. Олеся Гончара

Днепропетровская областная клиническая больнища им. И. И. Мечникова

\section{БИОЛОГИЧЕСКИЕ СВОЙСТВА БАКТЕРИЙ РОДА STAPHYLOCOCCUS, ВЫДЕЛЕННЫХ ОТ ПАЦИЕНТОВ ДНЕПРОПЕТРОВСКОЙ ОБЛАСТНОЙ КЛИНИЧЕСКОЙ БОЛЬНИЦЫ им. И. И. МЕЧНИКОВА}

\begin{abstract}
Исследованы биологические свойства 494 штаммов бактерий рода Staphylococcus, выделенных из патологического материала пациентов 15 отделений Днепропетровской областной клинической больницы им. И. И. Мечникова. Исследуемая микрофлора представлена четырьмя видами бактерий: Staphylococcus aureus, S. epidermidis, S. haemolyticus и S. saprophyticus. Самый распространенный возбудитель стафилококковых инфекций - золотистый стафилококк. Наибольшую чувствительность выделенные бактерии проявили к линезолиду, гентамицину и меропенему.
\end{abstract}

Y. Y. Nikulina, K. V. Lavrentyeva, N. V. Cherevach, O. A. Sirokvascha, A. I. Vinnikov

Oles Honchar Dnipropetrovsk National University

I. I. Mechnikov Dnipropetrovsk Region Clinical Hospital

\section{BIOLOGICAL PROPERTIES OF STAPHYLOCOCCUS GENUS STRAINS FROM PATIENTS OF MECHNIKOV DNIPROPETROVSK REGION CLINICAL HOSPITAL}

It was investigated the biological properties of 494 strains of Staphylococcus genus isolated from pathological material of patients from 15 Departments of Mechnikov Dnipropetrovsk Region Clinical Hospital. All microflora was presented by four bacteria species: Staphylococcus aureus, $S$. epidermidis, S. haemolyticus and $S$. saprophyticus. $S$. aureus was the most extended agent of infections. All bacteria were the most sensitive to linezolid, gentamycin and meropenem. 


\section{Вступ}

Стафілококова інфекція являє собою одну з найсерйозніших проблем охорони здоров'я, особливо протягом останнього десятиріччя, тому що інфекційні захворювання викликають вже і ті штами стафілококів, які раніше вважалися непатогенними, у першу чергу це стосується епідермального стафілокока $[1 ; 4]$. У наш час відомо понад 120 клінічних форм стафілококових інфекцій.

Актуальність проблеми стафілококових інфекцій визначається декількома аспектами. Стафілококи - представники нормальної мікрофлори людини, тому їх безпосереднє виявлення в організмі людини не $є$ доказом того, що саме вони - збудники того чи іншого захворювання. Їх етіологічна роль у виникненні багатьох захворювань суперечлива та потребує додаткових досліджень і удосконалених методів діагностики [7; 10]. Самолікування хворих, недотримання режимів стерилізації та дезінфекції медичного інструментарію та обладнання працівниками лікувальних і діагностичних закладів, висока частота генетичних рекомбінацій у стафілококів викликають появу антибіотикополірезистентних штамів i, як наслідок, спалахів внутрішньолікарняних інфекцій [8; 9]. Останні важко піддаються лікуванню антибіотиками, які займають провідне місце серед засобів хіміотерапії, що використовуються для боротьби зі стафілококовими інфекціями $[11 ; 12]$.

У зв'язку з цим мета роботи - оцінити біологічні властивості 494 штамів бактерій роду Staphylococcus, виділених із патологічного матеріалу від пацієнтів 15 відділень Дніпропетровської обласної клінічної лікарні ім. І. І. Мечникова, та визначити їх чутливість до антибіотиків різних фармакологічних груп.

\section{Матеріал і методи досліджень}

Для виділення та дослідження стафілококів у пацієнтів Дніпропетровської обласної клінічної лікарні ім. І. І. Мечникова здійснювали забір клінічного матеріалу з ліквору, сечі, мокротиння, поранень різного походження, носа, горла, очей, піхви з наступним висівом на кров'яний агар $[1 ; 2]$ та елективні для стафілококів середовища: жовтково-сольовий (ЖСА) та молочно-жовтково-сольовий агар (МЖСА). Надалі, згідно із Наказом МОЗ № 535 від 22.04.1985 p. [5], проводили мікроскопію забарвлених за Грамом мазків із вирослих колоній. Якщо за даними мікроскопії в досліджуваному матеріалі бактерій виявлялося мало, здійснювали посів у збагачувальне тіогліколеве середовище, а звідти знову на елективні. Через добу описували характер росту та морфологію колоній, що виросли. 3 усіх типів колоній робили мазки, забарвлювали за Грамом і мікроскопіювали, виявляючи типові грампозитивні коки. Видову ідентифікацію штамів проводили за допомогою мінімального диференціювального ряду тестів: утворення плазмокоагулази, гіалуронідази, лужної фосфатази, ДНКази, лецитинази, ліпази, уреази, стійкості до новобіоцину та поліміксину $B$, ферментації вуглеводів в анаеробних умовах [3; 4].

Чутливість до антибіотиків виділених штамів бактерій визначали дискодифузійним методом. Для дослідження антибіотикочутливості використано антибіотики різних фармакологічних груп: цефалоспорини - цефепім, цефуроксим аксетил, цефотаксим, цефтріаксон; аміноглікозиди - гентаміцин, амікацин, нетилміцин; $\beta$-лактами - ампіцилін, іміпенем, меропенем, оксацилін; фторхінолони - гатифлоксацин, ципрофлоксацин, моксифлоксацин, левофлоксацин, норфлоксацин; тетрацикліни доксициклін, тетрациклін; макроліди - еритроміцин; оксазолідинони - лінезолід. Результати обробляли статистично [6]. 


\section{Результати та їх обговорення}

Мікробіологічне дослідження матеріалу від пацієнтів при інфекційних захворюваннях різної етіології проведено на базі бактеріологічної лабораторії Дніпропетровської обласної клінічної лікарні ім. І. І. Мечникова. Від пацієнтів 15 відділень лікарні виділено 494 штами бактерій, які за комплексом культуральних та фізіологобіохімічних ознак віднесено до роду Staphylococcus. Усі виділені культури на кров'яному агарі утворювали непрозорі, злегка опуклі колонії середніх розмірів із гладенькою, блискучою поверхнею, чітко окресленим краєм, маслянистої консистенції. Патогенні штами утворювали навколо колоній прозорі зони гемолізу. При мікроскопії мазків клітини мали вигляд коків, зібраних у вигляді виноградного грона, забарвлених за Грамом позитивно.

На ЖСА стафілококи утворювали колонії із зоною помутніння навколо них (лецитиназна активність) і характерним райдужним ореолом по периферії (ліпазна активність), а колонії штамів $S$. aureus, крім того, синтезували жовто-оранжевий пігмент. Видову ідентифікацію штамів проводили за допомогою додаткових біохімічних тестів (табл. 1).

Табличя 1

Диференціальні ознаки стафілококів, виділених від паціснтів Дніпропетровської обласної клінічної лікарні ім. І. І. Мечникова

\begin{tabular}{|c|c|c|c|c|}
\hline Ознака & S. aureus & S. epidermidis & S. saprophyticus & S. haemolyticus \\
\hline Каротиноїдний пігмент & + & - & - & $\mathrm{V}$ \\
\hline Утворення плазмокоагулази & + & - & - & - \\
\hline Гіалуронідаза & + & - & - & - \\
\hline Термостабільна ДНК-аза & + & - & - & - \\
\hline Лужна фосфатаза & + & + & - & - \\
\hline Уреаза & $\mathrm{V}$ & + & + & - \\
\hline Стійкість до новобіоцину & - & - & + & - \\
\hline Стійкість до поліміксину В & + & + & - & - \\
\hline $\begin{array}{cl}\text { Анаеробна ферментація вуглецьумісних сполук: } \\
\text { - } & \text { маніту } \\
\text { - } & \text { трегалози } \\
\text { - } & \text { манози } \\
\text { - } & \text { мальтози } \\
\text { - } & \text { сахарози } \\
\text { - } & \text { фуранози }\end{array}$ & $\begin{array}{l}+ \\
+ \\
+ \\
+ \\
+ \\
+\end{array}$ & $\begin{array}{l}- \\
- \\
(+) \\
+ \\
+ \\
\mathrm{V}\end{array}$ & $\begin{array}{l}\mathrm{V} \\
+ \\
- \\
+ \\
+ \\
+\end{array}$ & $\begin{array}{l}\mathrm{V} \\
+ \\
- \\
+ \\
+ \\
\mathrm{V}\end{array}$ \\
\hline
\end{tabular}

Примітки: «-» - негативна реакція, «+» - позитивна реакція, $(+)$ - слабко позитивна реакція, «V» - варіабельна реакція.

Штами (243), які синтезували на ЖСА каротиноїдні пігменти, утворювали гіалуронідазу, ДНК-азу, фосфатазу, були стійкими до поліміксину $B$ і нестійкими до новобіоцину, ферментували маніт, трегалозу, манозу, мальтозу, сахарозу та фуранозу в анаеробних умовах віднесено до $S$. aureus. Із них 156 штамів були коагулазопозитивними, а 87 - коагулазонегативними. 95 штамів, що не синтезували каротиноїдних пігментів, плазмокоагулази, гіалуронідази, ДНК-ази, а утворювали фосфатазу та здійснювали анаеробну ферментацію мальтози та сахарози, характеризувались стійкістю до поліміксину $B$ і чутливістю до новобіоцину, віднесено до S. epidermidis. Для 85 штамів, які ідентифікували як S. saprophyticus, позитивними тестами виявилися синтез уреази та стійкість до новобіоцину, інші тести були негативними. Крім того, виділені культури були здатні до ферментації трегалози, мальтози, сахарози та фуранози в анаеробних умовах. Для 71 штаму, віднесеного до S. haemolyticus, відмічали відсутність синтезу всіх перелічених ферментів. Бактерії цього виду характеризувались чутливістю до но- 
вобіоцину та поліміксину $B$ і в анаеробних умовах ферментували лише мальтозу, трегалозу та сахарозу.

Весь спектр збудників стафілококових інфекцій у пацієнтів 15 відділень Дніпропетровської обласної клінічної лікарні ім. І. І. Мечникова представлений чотирма видами бактерій: S. aureus, S. epidermidis, S. saprophyticus та $S$. haemolyticus. Причому найчастіше штами $S$. aureus (табл. 2) виявлялися при флегмонах і абсцесах - у 57,2 \%, захворюваннях органів дихання - у 63,6 \%, запаленні суглобів - у 72,7 \% та кісткової тканини - у 82,6 \% пацієнтів. S. epidermidis найчастіше виявлявся при захворюваннях сечовидільної системи (у 28,6 \% випадків), а S. haemolyticus - при запаленні мозкових оболонок - у 43,8 \% пацієнтів. Найбільший відсоток виявлення S. saprophyticus установлений при захворюваннях органів травлення $(28,5 \%)$ і захворюваннях сечовидільної системи $(28,6 \%)$.

Таблиия 2

Наявність у біоматеріалі (\%) бактерій роду Staphylococcus при захворюваннях різних систем органів і тканин

\begin{tabular}{|l|c|c|c|c|}
\hline Ураження систем органів і тканин & S. aureus & S. epidermidis & S. haemolyticus & S. saprophyticus \\
\hline Органи травлення & 42,9 & 14,3 & 14,3 & 28,5 \\
\hline Органи дихання & 62,6 & 11,4 & 25,0 & 1,0 \\
\hline Сечовидільна система & 14,2 & 28,6 & 28,6 & 28,6 \\
\hline Мозкові оболонки & 25,0 & 18,7 & 43,8 & 12,5 \\
\hline Суглоби & 72,8 & 15,2 & 6,0 & 6,0 \\
\hline Кісткова тканина & 82,6 & 8,7 & 2,2 & 6,5 \\
\hline Флегмони та абсцеси & 57,2 & 8,7 & 14,5 & 19,6 \\
\hline
\end{tabular}

При дослідженні антибіотикочутливості виділених штамів бактерій встановлено, що 100,0 \% штамів $S$. aureus, виділених із клінічного матеріалу, мали стійкість до амікацину та іміпенему (табл. 3,4$)$.

Таблиия 3

Визначення чутливості (\%) до антибактеріальних препаратів штамів Staphylococcus aureus i $S$. epidermidis

\begin{tabular}{|c|c|c|c|c|c|c|c|}
\hline \multirow{2}{*}{\multicolumn{2}{|c|}{ Фармакологічна група антибіотиків }} & \multicolumn{3}{|c|}{ S. aureus } & \multicolumn{3}{|c|}{ S. epidermidis } \\
\hline & & \multirow{2}{*}{$\begin{array}{c}\text { стійкі } \\
33,3\end{array}$} & \multirow{2}{*}{$\begin{array}{c}\begin{array}{r}\text { помірно } \\
\text { чутливі }\end{array} \\
0,0\end{array}$} & \multirow{2}{*}{$\begin{array}{c}\text { чутливі } \\
66,7\end{array}$} & \multirow{2}{*}{$\begin{array}{c}\text { стійкі } \\
100,0\end{array}$} & \multirow{2}{*}{$\begin{array}{r}\begin{array}{r}\text { помірно } \\
\text { чутливі }\end{array} \\
0,0 \\
\end{array}$} & \multirow{2}{*}{$\begin{array}{c}\text { чутливі } \\
0,0\end{array}$} \\
\hline \multirow{5}{*}{ Цефалоспорини } & цефепім & & & & & & \\
\hline & цефуроксим & \multirow{2}{*}{0,0} & \multirow{2}{*}{100,0} & \multirow{2}{*}{0,0} & \multirow{2}{*}{0,0} & \multirow{2}{*}{100,0} & \multirow{2}{*}{0,0} \\
\hline & аксетил & & & & & & \\
\hline & цефотаксим & 50,0 & 0,0 & 50,0 & 0,0 & 100,0 & 0,0 \\
\hline & цефтріаксон & 50,0 & 0,0 & 50,0 & 0,0 & 100,00 & 0,0 \\
\hline \multirow{3}{*}{ Аміноглікозиди } & гентаміцин & 3,2 & 2,5 & 94,3 & 6,3 & 12,5 & 81,2 \\
\hline & амікацин & 100,0 & 0,0 & 0,0 & 0,0 & 0,0 & 100,0 \\
\hline & нетілміцин & 0,0 & 0,0 & 100,0 & 33,3 & 0,0 & 66,7 \\
\hline \multirow{4}{*}{$\beta$-лактами } & ампіцилін & 73,4 & 0,0 & 26,6 & 100,0 & 0,0 & 0,0 \\
\hline & іміпенем & 100,0 & 0,0 & 0,0 & 17,0 & 0,0 & 83,0 \\
\hline & меропенем & 50,0 & 0,0 & 50,0 & 0,0 & 0,0 & 100,0 \\
\hline & оксацилін & 18,6 & 0,7 & 80,7 & 73,5 & 4,0 & 22,5 \\
\hline \multirow{5}{*}{ Фторхінолони } & гатифлоксацин & 7,2 & 23,1 & 69,7 & 14,0 & 16,0 & 70,0 \\
\hline & ципрофлоксацин & 4,0 & 3,3 & 92,7 & 27,8 & 11,0 & 61,2 \\
\hline & моксифлоксацин & 2,9 & 21,3 & 75,8 & 1,8 & 47,9 & 50,3 \\
\hline & левофлоксацин & 0,5 & 0,5 & 99,0 & 9,0 & 12,6 & 78,4 \\
\hline & норфлоксацин & 0,0 & 0,0 & 100,0 & 25,0 & 0,0 & 75,0 \\
\hline \multirow{2}{*}{ Тетрацикліни } & доксициклін & 2,7 & 26,3 & 71,0 & 6,1 & 14,1 & 79,8 \\
\hline & тетрациклін & 33,5 & 7,5 & 59,0 & 57,6 & 14,8 & 27,6 \\
\hline Макроліди & еритроміцин & 27,5 & 23,5 & 49,0 & 45,4 & 24,6 & 30,0 \\
\hline Оксазолідинони & лінезолід & 7,3 & 0,2 & 92,5 & 3,0 & 0,0 & 97,0 \\
\hline
\end{tabular}


Найактивнішими антибіотичними препаратами відносно $S$. aureus виявилися аміноглікозиди - гентаміцин (94,3 \% штамів), нетилміцин (100,0 \%), антибактеріальні препарати фторхінолонової групи - ципрофлоксацин (92,7 \%), левофлоксацин (99,0 \%), норфлоксацин (100,0 \%) та лінезолід (92,5\%).

Що стосується S. epidermidis, то 100,0 \% штамів цього виду виявилися стійкими до цефепіму та ампіциліну. Проте 100,0 \% штамів $S$. epidermidis проявили чутливість до амікацину та меропенему. Також високочутливими S. epidermidis були до гентаміцину (81,2 \% штамів), іміпенему (83,0 \%) та лінезоліду (97,0 \%).

Штами $S$. haemolyticus проявили стійкість до еритроміцину, ципрофлоксацину та ампіциліну (див. табл. 4). Резистентними до цих препаратів були 63,3, 69,1 і 73,1 \% штамів відповідно. Поряд із цим 100,0 \% штамів чутливі до цефотаксиму, цефтріаксону, нетилміцину та меропенему. Відносно високу чутливість $S$. haemolyticus проявили до лінезоліду (95,2 \%), іміпенему (90,0 \%), гентаміцину (88,1 \%) та оксациліну $(80,7 \%)$.

Що стосується S. saprophyticus, то 100,0 \% штамів проявили стійкість до цефалоспоринів (цефепіму, цефуроксиму аксетилу, цефотаксиму, цефтріаксону), аміноглікозидів (амікацину, нетилміцину, ампіциліну) та фторхінолонів (моксифлоксацину та норфлоксацину). Проте 100,0 \% штамів S. saprophyticus чутливі до гентаміцину та меропенему.

Таблиия 4

Визначення чутливості (\%) до антибактеріальних препаратів штамів Staphylococcus haemolyticus та S. saprophyticus

\begin{tabular}{|c|c|c|c|c|c|c|c|}
\hline \multirow{2}{*}{\multicolumn{2}{|c|}{ Фармакологічна група антибіотиків }} & \multicolumn{3}{|c|}{ S. haemolyticus } & \multicolumn{3}{|c|}{ S. saprophyticus } \\
\hline & & \multirow{2}{*}{$\frac{\text { стійкі }}{33,4}$} & \multirow{2}{*}{$\begin{array}{c}\begin{array}{c}\text { помірно } \\
\text { чутливі }\end{array} \\
33,3\end{array}$} & \multirow{2}{*}{$\begin{array}{c}\text { чутливі } \\
33,3\end{array}$} & \multirow{2}{*}{$\begin{array}{c}\text { стійкі } \\
100,0\end{array}$} & \multirow{2}{*}{$\begin{array}{c}\begin{array}{r}\text { помірно } \\
\text { чутливі }\end{array} \\
0,0\end{array}$} & \multirow{2}{*}{$\begin{array}{c}\text { чутливі } \\
0,0\end{array}$} \\
\hline \multirow{5}{*}{ Цефалоспорини } & цефепім & & & & & & \\
\hline & цефуроксим & 50,0 & 50,0 & 0,0 & 100,0 & 0,0 & 0,0 \\
\hline & аксетил & 50,0 & 50,0 & 0,0 & 100,0 & 100,0 & 100,0 \\
\hline & цефотаксим & 0,0 & 0,0 & 100,0 & 100,0 & 0,0 & 0,0 \\
\hline & цефтріаксон & 0,0 & 0,0 & 100,0 & 100,0 & 0,0 & 0,0 \\
\hline \multirow{3}{*}{ Аміноглікозиди } & гентаміцин & 11,9 & 0,0 & 88,1 & 0,0 & 0,0 & 100,0 \\
\hline & амікацин & 33,3 & 0,0 & 66,7 & 100,0 & 0,0 & 0,0 \\
\hline & нетілміцин & 0,0 & 0,0 & 100,0 & 100,0 & 0,0 & 0,0 \\
\hline \multirow{4}{*}{$\beta$-лактами } & ампіцилін & 73,1 & 0,0 & 26,9 & 100,0 & 0,0 & 0,0 \\
\hline & іміпенем & 10,0 & 0,0 & 90,0 & 50,0 & 50,0 & 0,0 \\
\hline & меропенем & 0,0 & 0,0 & 100,0 & 0,0 & 0,0 & 100,0 \\
\hline & оксацилін & 18,6 & 0,7 & 80,7 & 90,0 & 10,0 & 0,0 \\
\hline \multirow{5}{*}{ Фторхінолони } & гатіфлоксацин & 1,9 & 26,0 & 72,1 & 0,0 & 0,0 & 100,0 \\
\hline & ципрофлоксацин & 69,1 & 4,8 & 26,1 & 50,0 & 0,0 & 50,0 \\
\hline & моксифлоксацин & 16,1 & 7,8 & 76,1 & 100,0 & 0,0 & 0,0 \\
\hline & левофлоксацин & 9,0 & 26,4 & 64,6 & 0,0 & 16,7 & 83,3 \\
\hline & норфлоксацин & 55,6 & 0,0 & 44,4 & 100,0 & 0,0 & 0,0 \\
\hline \multirow{2}{*}{ Тетрацикліни } & доксициклін & 14,4 & 17,4 & 68,2 & 25,0 & 0,0 & 75,0 \\
\hline & тетрациклін & 29,0 & 40,0 & 31,0 & 25,0 & 0.0 & 75,0 \\
\hline Макроліди & еритроміцин & 63,3 & 20,0 & 16,7 & 25,0 & 50,0 & 25,0 \\
\hline Оксазолідинони & лінезолід & 3,8 & 1,0 & 95,2 & 83,4 & 0,0 & 16,6 \\
\hline
\end{tabular}

Універсальними препаратами для лікування стафілококових інфекцій виявилися аміноглікозид гентаміцин, $\beta$-лактам меропенем і оксазолідинон лінезолід.

\section{Висновки}

Виділено 494 штами бактерій роду Staphylococcus від пацієнтів 15 відділень Дніпропетровської обласної клінічної лікарні ім. I. I. Мечникова. Досліджена мікрофлора представлена чотирма видами стафілококів: S. aureus, S. epidermidis, S. haemolyticus ra $S$. saprophyticus. Найпоширенішим збудником стафілококових інфекцій, а са- 
ме абсцесів, флегмон, захворювань органів дихання, запалення суглобів і кісткової тканини виявився $S$. aureus. S. haemolyticus найчастіше виділявся при запаленнях мозкових оболонок. Інші види стафілококів практично з однаковою частотою виявлялися при захворюваннях сечовидільної системи. Серед протестованих антибактеріальних препаратів найефективнішими відносно всіх видів стафілококів були аміноглікозид гентаміцин, $\beta$-лактам меропенем і оксазолідинон лінезолід.

\section{Бібліографічні посилання}

1. Воробьев А. А. Медицинская и санитарная микробиология. - М. : Академия, 2003. - 464 с.

2. Практична мікробіологія / С. С. Климнюк, І. О. Ситник, М. С. Творко та ін. - Т. : Укрмедкнига, 2002. $-352 \mathrm{c}$.

3. Поздеев О. К. Медицинская микробиология / О. К. Поздеев, В. И. Покровский. - М. : Геотармед, 2001. $-656 \mathrm{c.}$

4. Покровский В. И. Стафилококки. - М. : Медицина, 2005. - 340 с.

5. Приказ Минздрава СССР от 22.04.1985 г. № 535 об унификации микробиологических (бактериологических) методов исследования, применяемых в клинико-диагностических лабораториях лечебно-профилактических учреждений. -12 c.

6. Решедько Г. К. Особенности определения чувствительности микроорганизмов дискодиффузионным методом // Клиническая микробиология и антимикробная химиотерапия. 2001. - T. 3, № 4. - C. 28-32.

7. Bengualid V. Not all coagulase negative Staphylococcus are created equal / V. Bengualid, J. Krishnaprakash, R. Tan // New York Medical Journal. - 2009. - Vol. 4, N 2. - P. 17-21.

8. Bonten M. Microcin for preventing Staphylococcus aureus infections / M. Bonten, R. Wenzel, J. Kluymons // Journal of Perioperative Practice. - 2009. - Vol. 102, N 11. - P. 120-124.

9. Combes A. Impact of methicillin resistance on outcome of Staphylococcus aureus ventilatorassociated pneumonia / A. Combes, C. Luyt, M. Wolf // Respiratory and Critical Care Medicine.2004. - Vol. 170, N 10. - P. 786-792.

10. Derycke L. Staphylococcus aureus and chronic airway disease / L. Derycke, N. Pere // World Allergy Organization Journal. - 2010. - Vol. 3, N 8. - P. 223-228.

11. Guzman-Blanco M. Epidemiology of meticillin-resistant Staphylococcus aureus (MRSA) in Latin America / M. Guzman-Blanco, C. Mejia, R. Isturiz // International Journal of Antimicrobial Agents. 2009. - Vol. 5, N 6. - P. 304-308.

12. Zimmerman U. P. Occurrence and significance of $S$. aureus resistant to gentamicin // Antinfection. Drugs and Chemoter. - 2008. - Vol. 16, N 2. - P. 147-149.

Надійшла до редколегї 12.04.2011 